\title{
A Blend of Essential Plant Oils Used as an Additive to Alter Silage Fermentation or Used as a Feed Additive for Lactating Dairy Cows
}

\author{
L. Kung Jr., ${ }^{\star 1}$ P. Williams, $\dagger^{2}$ R. J. Schmidt, ${ }^{*}$ and W. Hu* \\ *Department of Animal and Food Sciences, University of Delaware, 531 South College Avenue, Newark 19716-2150 \\ †Dutch State Mines Nutritional Products Inc., 45 Waterview Blvd., Parsippany, NJ 07054
}

\begin{abstract}
A blend of essential plant oils was evaluated for its effects on silage fermentation and animal performance. In the first experiment, the blend of essential oils was mixed with freshly chopped whole-plant corn to achieve a concentration of 0,40 , or $80 \mathrm{mg}$ of active product per kilogram of fresh forage weight. Whole-plant corn was also mixed with a buffered propionic acid-based product at $0.2 \%$ of fresh forage weight. The blend of essential oils did not affect the populations of yeasts, molds, lactic acid bacteria, or enterobacteria; the fermentation end products; or the aerobic stability of the corn silage. Addition of the buffered propionic acid additive moderately reduced the production of acids during fermentation and resulted in a small reduction in the numbers of yeasts after ensiling, but did not affect aerobic stability. In a second experiment, 30 Holstein cows (4 primiparous and 26 multiparous) averaging 118 $\pm 70 \mathrm{~d}$ in milk and producing $38 \pm 16 \mathrm{~kg}$ of milk/d were fed a total mixed ration, once daily, that consisted of (on a DM basis) $25 \%$ corn silage, $15 \%$ alfalfa silage, $10 \%$ alfalfa hay, and $50 \%$ concentrate. One-half of the cows were fed a blend of essential oils that was mixed directly into their total mixed ration to provide $1.2 \mathrm{~g} /$ cow per $\mathrm{d}$ for $9 \mathrm{wk}$. Cows fed the essential oils ate 1.9 $\mathrm{kg}$ more dry matter/d and produced $2.7 \mathrm{~kg}$ more $3.5 \%$ fat-corrected milk/d than did cows fed the control diet. The percentages of milk fat and protein, the somatic cell count numbers, and the concentrations of milk urea nitrogen were unaffected by treatment. Feed efficiency, change in body weight, and change in body condition scoring were also similar between treatments. After 12 $\mathrm{h}$ of incubation, the addition of a moderate dose and a high dose of essential oils to in vitro ruminal fermentations had no effect on the concentration of total VFA
\end{abstract}

Received May 28, 2008.

Accepted August 6, 2008.

${ }^{1}$ Corresponding author: lksilage@udel.edu

${ }^{2}$ Current address: Advantec Associates Inc., 5402 Tufts Street, Davis, CA 95618. compared with the control treatment. However, they decreased the molar proportions of acetic, butyric, and valeric acids and increased the proportion of propionic acid. The blend of essential oils evaluated in this study altered in vitro ruminal fermentation and improved animal performance when fed directly to cows, but it did not affect the fermentation or aerobic stability of corn silage.

Key words: essential oil, lactating cow, rumen, silage

\section{INTRODUCTION}

Essential oils are aromatic oily liquids extracted from plant material via expression, fermentation, or, commonly, a distillation method. They have a wide range of antimicrobial activities (Chao et al., 2000; Burt, 2004), and interest in their use has been heightened because of the current emphasis on the use of natural compounds. Essential oils have been shown to accumulate in cell membranes and disrupt their integrity, leading to leakage of enzymes and metabolites (Smid and Gorris, 1999). Structure-function relationships associated with polar groups, number of double bonds, molecular size, and molecular solubility may have marked effects on their activities (Kamel, 2001). Essential oils may have applications in ruminant nutrition because fermentations in the silo and rumen are dependent on microbial activities that may be affected by their use.

Essential oils have been shown to affect several rumen processes (Calsamiglia et al., 2006), but the results have been inconsistent. For example, deaminase activity in the rumen was decreased by their addition (Newbold et al., 2004; Wallace, 2004). Specifically, McIntosh et al. (2003) observed that Peptostreptococcus anaerobius, Clostridium stricklandii, and Prevotella ruminicola, species known as "hyperammonia-producing" bacteria (Russell et al., 1991), were inhibited by a commercial blend of plant oils and suggested that the main effect of plant oils occurred during the final phase of protein degradation. Ferme et al. (2004) also observed a reduction in bacteria from the proteolytic genus Prevotella in a ruminal continuous culture system when treated 
with a garlic extract. However, Benchaar et al. (2006) and Castillejos et al. (2005) reported that a blend of essential oils had no effect on ruminal ammonia. Essential oils have also had varied effects on ruminal VFA patterns. Dried extracts of Lavandula officinalis stimulated in vitro rumen production of VFA (Broudiscou and Lassalas, 2000). Castillejos et al. (2005) reported that a blend of essential oils (Crina, DSM Nutritional Products Ltd., Parsippany, NJ) increased the acetate:propionate ratio in ruminal fermentations, but that effects may vary based on the diet and conditions in the rumen. Cardozo et al. (2004), using an in vitro system with ruminal fluid from steers fed a high-concentrate diet, reported that cinnamon oil and cinnamaldehyde increased the acetate:propionate ratio and decreased VFA concentration when the culture $\mathrm{pH}$ was 7 . However, when the culture $\mathrm{pH}$ was 5.5 , the acetate:propionate ratio decreased and total VFA increased.

Although not directly studied to date, essential oils may have the potential to alter the ensiling of forage crops via their effects on microbes associated with this process. Kivanc et al. (1991) reported that cumin (from Cuminum cyminum L.) stimulated growth and lactic acid production of Lactobacillus plantarum. This bacterium is a common component of inoculants added to stimulate silage fermentation (Kung et al., 2003). Capsaicin, from peppers (Capsicum), has been shown to inhibit species of Clostridium (Cichewicz and Thorpe, 1996; Kamel, 2001) that can dominate the fermentation process in wet silages and lead to extensive degradation of nutrients. In addition, clove and oregano extracts (containing eugenol) have been shown to be highly effective in inhibiting the growth of Clostridium botulinum (Ismaiel and Pierson, 1990). Species of yeasts that are closely associated with aerobic spoilage in silages have also been inhibited by some essential oils. For example, carvacrol inhibited the growth of some strains of Saccharomyces cerevisiae (Knowles and Roller, 2001), and thymol has inhibited the growth of Debaryomyces hansenii (Curtis et al., 1996). Juglal et al. (2002) reported antifungal activities of essential oils toward fungi-producing mycotoxins. To date, we know of no published studies evaluating the use of essential oils to alter the fermentation and aerobic stability of corn silage.

The objectives of this study were to 1) determine the effect of a specific blend of essential oils on the fermentation and aerobic stability of corn silage, and 2) to determine its effects on DMI, milk production, and milk composition when fed directly to lactating cows.

\section{MATERIALS AND METHODS}

\section{Silage Experiment}

Corn forage was harvested at 28 to $29 \%$ of DM with a New Holland FP230 pull-type harvester (New Holland North America, New Holland, PA) with an on-board kernel processor. Chop length was set to achieve a theoretical cut of $0.95 \mathrm{~cm}$. Four piles of chopped forage were treated with the following: 1) nothing, 2) a water-soluble formulation of essential oils (Crina, DSM Nutritional Products Ltd., $40 \%$ active ingredients) supplying 40 $\mathrm{mg}$ of active ingredients $/ \mathrm{kg}$ of wet forage, 3 ) the same formulation supplying $80 \mathrm{mg}$ of essential oils $/ \mathrm{kg}$ of wet forage, or 4) $0.2 \%$ of a liquid buffered propionic acidbased product (Ultra Curb, Kemin Industries, West Des Moines, Iowa)/ $t$ of wet forage. The Crina product was a defined and patented blend of natural and naturalidentical essential oil compounds that included thymol, eugenol, vanillin, and limonene on an organic carrier (McIntosh et al., 2003). The low treatment was calculated hypothetically to supply the equivalent of 1,000 $\mathrm{mg}$ of the active essential oil blend for a cow consuming $25 \mathrm{~kg}$ of wet silage/d. All treatments were mixed in 250 $\mathrm{mL}$ of water and sprayed onto the chopped forage mass (50 kg of wet forage) while mixing. A similar amount of water was added to the control forage. Untreated and treated forages were packed into replicated mini silos (approximately $300 \mathrm{~g}$ capacity, $5 \mathrm{~cm}$ diameter $\times 20 \mathrm{~cm}$ height) and 4 silos were opened for each treatment after 3 and $8 \mathrm{~d}$ of ensiling. Approximately $14 \mathrm{~kg}$ of untreated and treated forages were also packed into 20-L macro silos (27 cm diameter $\times 36 \mathrm{~cm}$ height, 4 per treatment) and ensiled for $256 \mathrm{~d}$. Packing densities in the silos were $217 \pm 7.5 \mathrm{~kg}$ of $\mathrm{DM} / \mathrm{m}^{3}$. Silos were stored in a room with temperatures between 20 and $26^{\circ} \mathrm{C}$.

Fresh forages and silage samples from each silo were evaluated for DM content by drying duplicate samples for $48 \mathrm{~h}$ in a forced-air oven set at $60^{\circ} \mathrm{C}$. Water extracts were prepared from fresh and ensiled samples by mixing $25 \mathrm{~g}$ of forage with $225 \mathrm{~mL}$ of $25 \%$ Ringer's solution (Oxoid BR52, Basingstoke, UK) and homogenizing this mix for $1 \mathrm{~min}$. The $\mathrm{pH}$ of the water extract was measured, and a portion of it was filtered through Whatman 54 filter paper (Whatman, Clifton, NJ) and acidified with $50 \% \mathrm{H}_{2} \mathrm{SO}_{4}$ and frozen before analysis for ammonia- $\mathrm{N}$ by using a phenol-hypochlorite method (Okuda et al., 1965). Lactic acid and VFA were analyzed on the filtered water extract as described by Kung and Ranjit (2001). Water-soluble carbohydrates in forages and silages were determined by using the colorimetric method described by Nelson (1944). A portion of the water extract was pour plated by using serial 10-fold 
dilutions on violet red bile glucose agar (Oxoid CM485) with a single overlay to determine the number of enterobacteria (d 0, 3, and 8 only) in samples. Plates were incubated under aerobic conditions at $36^{\circ} \mathrm{C}$ for $18 \mathrm{~h}$. Yeast and molds (d 0, 3, 8, and 256) were determined by pour plating in malt extract agar (Oxoid CM59) that had been acidified $(0.5 \% \mathrm{vol} / \mathrm{vol})$ after autoclaving with lactic acid (85\%). Plates were incubated under aerobic conditions at $32^{\circ} \mathrm{C}$ for $48 \mathrm{~h}$. Lactic acid bacteria (d 0 , 3 , and 8 only) were enumerated on De Man, Rogosa, Sharpe agar (Oxoid CM0361) and incubated at $32^{\circ} \mathrm{C}$ for $48 \mathrm{~h}$. Dried forage and silage samples were ground through a 1-mm screen of a Cyclone Sample Mill (Udy Corp., Fort Collins, CO). Samples were analyzed for $\mathrm{N}$ by total combustion of the sample (Leco CNS 2000 Analyzer, Leco, St. Joseph, MI). Aerobic stability was determined on silages that had been ensiled for $256 \mathrm{~d}$ by exposing $3 \mathrm{~kg}$ of loose silage to air in 20-L buckets. The buckets were covered with cheesecloth to allow air to infiltrate the silage mass and prevent the silage from drying out and becoming contaminated. A thermocouple wire was inserted in the middle of the silage mass. The wire was attached to a data logger (model number CR10X, Campbell Scientific Inc., Logan, UT) that recorded the temperature every $10 \mathrm{~min}$. Data were averaged every $2 \mathrm{~h}$ and aerobic stability was defined as the number of hours the silage remained stable before a $2^{\circ} \mathrm{C}$ increase in temperature above the ambient temperature (Kung and Ranjit, 2001).

\section{Lactation Trial}

This study was approved by the Animal Care and Use Committee of the College of Agriculture and Natural Resources, University of Delaware, and followed the care and management of animals as per accepted guidelines (Agricultural Animal Care and Use Committee, 1989). Thirty lactating cows (4 primiparous and 26 multiparous), averaging $118 \pm 70$ DIM and $38 \pm 16 \mathrm{~kg}$ of milk/d, were housed in a free-stall barn and fed via Calan gates (American Calan, Northwood, NH) to measure individual daily intake. Cows were fed a TMR once daily that consisted of (on a DM basis) $25 \%$ corn silage, $15 \%$ alfalfa silage, $10 \%$ alfalfa hay, and $50 \%$ concentrate (Tables 1 and 2). The rations were balanced to meet NRC (2001) requirements for cows producing $40 \mathrm{~kg}$ of milk/d, $3.5 \%$ fat, and $3.1 \%$ protein and weighing 680 $\mathrm{kg}$. Cows had access to fresh water at all times. Cows were allowed to exercise twice daily in a dirt lot for approximately 1 to $2 \mathrm{~h}$. All cows were supplemented with a dry additive mixture of essential plant oils blended in limestone. Fifty grams of the limestone-essential oil blend (Crina) was mixed by hand into the TMR of all cows to provide a daily intake of $0.6 \mathrm{~g}$ of essential oils/
Table 1. Composition (\%, DM basis) of concentrate mixed into the TMR during the lactation experiment

\begin{tabular}{lc}
\hline Ingredient & Amount, $\%$ \\
\hline Corn meal (fine) & 42.42 \\
Distillers dried grains & 10.72 \\
Corn gluten feed & 10.72 \\
Soybean roasted & 7.18 \\
Soybean meal (47.5\%) & 5.58 \\
Wheat middlings & 5.48 \\
Molasses blend $^{1}$ & 4.16 \\
Corn starch $^{2}$ & 2.69 \\
Protein blend $^{2}$ & 1.84 \\
Fat blend & 1.67 \\
Sesquicarbonate & 2.04 \\
Limestone (37\%) $_{\text {Corn gluten }(60 \% \text { CP) }}$ & 1.76 \\
Salt $^{3}$ Magnesium oxide & 1.50 \\
Urea $_{\text {Selenium }(0.06 \%)}$ ) & 0.96 \\
Trace minerals $^{4}$ & 0.57 \\
Vitamins $^{5}$ & 0.51 \\
\hline
\end{tabular}

${ }^{1}$ Contained (DM basis) $0.5 \% \mathrm{Ca}, 0.03 \mathrm{~g}$ of $\mathrm{Cu} / \mathrm{kg}, 5.0 \%$ crude fat, $3.0 \%$ $\mathrm{CP}, 0.50 \mathrm{~g}$ of $\mathrm{I} / \mathrm{kg}, 0.40 \% \mathrm{Mg}, 1.50 \mathrm{mcal} / \mathrm{kg}$ of $\mathrm{NE}_{\mathrm{L}}, 45.5 \% \mathrm{NSC}, 3.2 \%$ $\mathrm{K}, 0.70 \% \mathrm{~S}, 63 \%$ total digestible nutrients, $0.50 \% \mathrm{P}, 0.01 \mathrm{~g}$ of $\mathrm{Zn} / \mathrm{kg}$, 0.94 undegradable intake protein.

${ }^{2}$ Dried blood meal, hydrolyzed poultry feathers, fishmeal, calcium carbonate, and ethoxyquin.

${ }^{3}$ Feed-grade combination of tallow, poultry, and porcine fats.

${ }^{4}$ Contained $2.1 \% \mathrm{Ca}, 1.6 \mathrm{~g}$ of $\mathrm{Co} / \mathrm{kg}, 40 \mathrm{~g}$ of $\mathrm{Cu} / \mathrm{kg}, 4.0 \mathrm{~g}$ of I $/ \mathrm{kg}, 6.0$ $\mathrm{g}$ of $\mathrm{Fe} / \mathrm{kg}, 150 \mathrm{~g}$ of $\mathrm{Mn} / \mathrm{kg}, 13.0 \% \mathrm{~S}, 160 \mathrm{~g}$ of $\mathrm{Zn} / \mathrm{kg}$.

${ }^{5}$ Contained (DM basis) $26,400 \mathrm{kIU}$ of vitamin $\mathrm{A} / \mathrm{kg}, 8,800 \mathrm{kIU} / \mathrm{kg}$ of vitamin $\mathrm{D}$, and $165,000 \mathrm{IU}$ of vitamin $\mathrm{E} / \mathrm{kg}$.

cow per d during the 14-d pretreatment period. This was done to accustom all cows to the smell and taste of the essential oils. At the end of the pretreatment period, cows were blocked by lactation number, pretreatment milk production, DIM, and lactation number and then randomly allocated to 1 of 2 treatments. During a 9-wk treatment period, one-half of the cows received the base TMR without supplementation, and the remaining half of the cows were fed the same TMR supplemented with essential oils to provide an intake of $1.2 \mathrm{~g} / \mathrm{cow}$ per $\mathrm{d}$. Control cows were supplemented with only the limestone carrier.

A computer recorded milk production from each cow twice daily at approximately 0600 and $1800 \mathrm{~h}$. Once weekly, milk was sampled proportionately to milk yield from consecutive p.m. and a.m. milkings and analyzed for fat, protein, lactose, MUN, and SCC (Dairy One, University Park, PA). Body weights were recorded on 2 consecutive days at the beginning and end of the study. Body condition scores (Wildman et al., 1982) were recorded at the beginning and end of the study. Feed offered and refused was measured daily. Samples of all feeds were collected 3 times weekly and composited on a weekly basis. Once weekly, a representative sample 
Table 2. Measured nutrient composition of the individual feeds (average value of 3 composite samples) and TMR (average value from 9 weekly composite samples) fed to lactating cows throughout the lactation study

\begin{tabular}{|c|c|c|c|c|c|c|}
\hline Item & Alfalfa hay & Alfalfa silage & Corn silage & Concentrate & Control TMR & $\mathrm{BEO}^{1} \mathrm{TMR}$ \\
\hline $\mathrm{CP}, \%$ & 16.24 & 19.81 & 8.96 & 20.29 & $16.36 \pm 0.58$ & $16.43 \pm 0.78$ \\
\hline $\mathrm{ADF}, \%$ & 45.62 & 37.46 & 29.25 & 6.44 & $25.84 \pm 2.25$ & $25.97 \pm 2.85$ \\
\hline NDF, \% & 52.64 & 43.45 & 46.71 & 17.67 & $35.44 \pm 2.09$ & $35.32 \pm 2.37$ \\
\hline Ash, $\%$ & 7.01 & 12.04 & 3.86 & 5.67 & $8.14 \pm 0.48$ & $8.32 \pm 1.56$ \\
\hline Starch, \% & - & - & - & 38.67 & $18.79 \pm 1.87$ & $18.88 \pm 1.79$ \\
\hline $\mathrm{P}, \%$ & 0.29 & 0.33 & 0.21 & 0.55 & $0.35 \pm 0.01$ & $0.35 \pm 0.02$ \\
\hline $\mathrm{Mg}, \%$ & 0.18 & 0.38 & 0.16 & 0.56 & $0.30 \pm 0.02$ & $0.31 \pm 0.02$ \\
\hline $\mathrm{K}, \%$ & 2.38 & 3.02 & 1.01 & 0.98 & $1.46 \pm 0.06$ & $1.51 \pm 0.14$ \\
\hline \multicolumn{7}{|c|}{ Particle size distribution, ${ }^{2} \%$} \\
\hline Screen 1 & - & - & - & - & $11.62 \pm 2.54$ & $11.32 \pm 2.92$ \\
\hline Screen 2 & - & - & - & - & $23.78 \pm 3.37$ & $22.60 \pm 2.70$ \\
\hline Screen 3 & - & - & - & - & $41.38 \pm 3.89$ & $42.10 \pm 4.71$ \\
\hline
\end{tabular}

${ }^{1}$ TMR supplemented with a blend of essential oils (Crina, DSM Nutritional Products Ltd., Parsippany, NJ) to supply $1.2 \mathrm{~g} /$ cow per d.

${ }^{2}$ As determined on a Penn State Particle Size Separator (Pennsylvania State University, State College, PA) with 4 screens.

of each TMR was subjected to quantitative measurements of particle size by using a Penn State Particle Size Separator (Pennsylvania State University, State College, PA). Dry matter of the feed samples was determined in a forced-air oven at $60^{\circ} \mathrm{C}$ for $48 \mathrm{~h}$. Dietary ingredients were adjusted on a weekly based on the DM content of the feeds. After drying, feed samples were ground through a Wiley mill (1-mm screen, Arthur H. Thomas, Philadelphia, PA) and analyzed for laboratory DM $\left(100^{\circ} \mathrm{C}\right.$ oven for $\left.24 \mathrm{~h}\right), \mathrm{NDF}$ by using sulfite and amylase (Van Soest et al., 1991), and ADF (Robertson and Van Soest, 1981). Total N was determined as described previously for corn silages. Starch was analyzed by the Cumberland Valley Analytical Services laboratory (Maugansville, MD) and the mineral content of the TMR was analyzed by inductively coupled plasma emission spectrometry on a composite sample from each period (University of Delaware Soil Testing Program, Newark, DE).

\section{In Vitro Ruminal Fermentation}

The effect of the blend of essential oils on ruminal in vitro fermentation was tested by using the system described by Goering and Van Soest (1970) with some modifications. Rumen inoculum was withdrawn from a fistulated Holstein steer, fed once daily for ad libitum intake of a TMR composed of $35 \%$ corn silage, $15 \%$ alfalfa silage, $5 \%$ alfalfa hay, and approximately $45 \%$ of a concentrate mix (DM basis). Ruminal fluid was strained through 4 layers of cheesecloth, mixed in a 1-to-4 proportion with a phosphate-bicarbonate buffer, and purged constantly with anaerobic-grade $\mathrm{CO}_{2}$. The primary modification included using $90-\mathrm{mL}$ polycarbonate tubes containing $50 \mathrm{~mL}$ of culture fluid with $0.5 \mathrm{~g}$ of the same diet used during the lactation experiment and ground through a $2-\mathrm{mm}$ screen. Five replicate tubes were prepared for each treatment. The tubes were purged with $\mathrm{CO}_{2}$ before sealing with butyl rubber stoppers fitted with gas-release valves. Tubes were placed in a heated $\left(39^{\circ} \mathrm{C}\right)$ orbital shaker $(100 \mathrm{rpm})$. Treatments were nothing, the dry blend of essential oils (Crina) at a physiological dose $(0.044 \mathrm{mg} / \mathrm{kg}$ of feed DM), and the blend of essential oils at a level 25 times greater $(1.111 \mathrm{mg} / \mathrm{kg}$ of feed DM). Based on the experimental conditions described previously, feeding the physiological dose would provide a cow consuming $27 \mathrm{~kg}$ of DM/d with $1.2 \mathrm{~g}$ of active ingredient/d. The blend of essential oils was dissolved in $50 \%$ ethanol, and $1 \mathrm{~mL}$ was added to each tube. The equivalent amount of ethanol alone was added to control tubes. Samples were taken at 12 h. A 10-mL aliquot was sampled from each tube, and ruminal fluid $\mathrm{pH}$ was measured immediately. Ruminal fluid was then acidified with $50 \mu \mathrm{L}$ of $50 \% \mathrm{H}_{2} \mathrm{SO}_{4}$ and frozen $\left(-20^{\circ} \mathrm{C}\right)$ before analysis for VFA. Volatile fatty acids were determined by GC as described by Kung and Ranjit (2001).

\section{Statistical Analysis}

Data from the silage experiment, the lactation trial, and the ruminal in vitro fermentation were analyzed as completely randomized designs by using the general linear models procedure (SAS Institute Inc., Cary, NC). Data from the pretreatment period of the lactation study were used for covariate adjustment. Tukey's test 
Table 3. The $\mathrm{pH}$, chemical (DM basis) composition, and microbial composition (wet basis) of freshly chopped whole-plant corn after treatment but before ensiling (analysis from a single sample for each treatment)

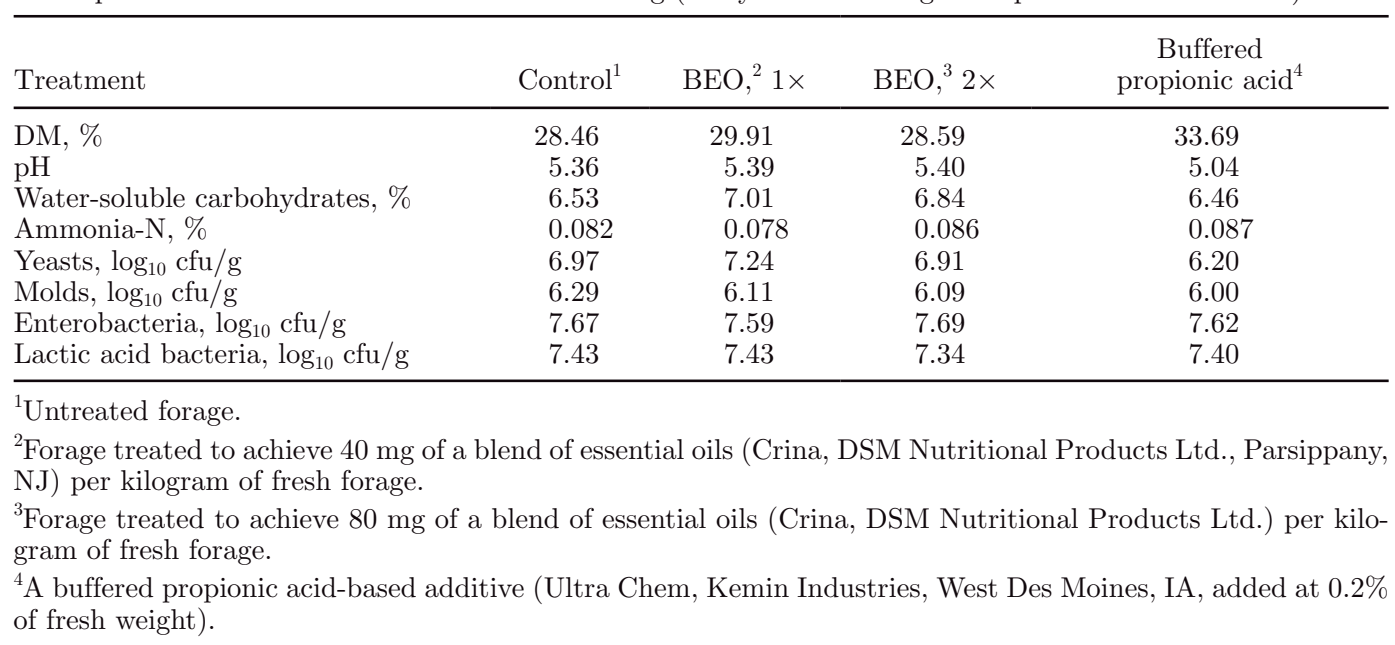

(Snedecor and Cochran, 1980) was used to test treatment means $(P<0.05)$ of the silage experiment and lactation trial. For the rumen in vitro data, contrasts were constructed to compare 1) the control versus the addition of essential oils, and 2) the addition of essential oils at a physiological dose versus at a level 25 times greater. Significance was defined at $P<0.05$.

\section{RESULTS AND DISCUSSION}

\section{Silage Experiment}

The chemical and microbial composition of freshly chopped forages is shown in Table 3 . The chemical and microbial compositions of silages after 3 and $8 \mathrm{~d}$ are not shown because the addition of the essential oils had only minor effects on the measured variables compared with untreated silage. We hypothesized that the blend of essential oils used in the current study might be useful as a silage additive. Specifically, past research has shown that compounds such as limonene (Figueiredo et al., 2008) and eugenol (Kim et al., 2006) had no effects on lactic acid bacteria and thus would not pose a problem for these beneficial bacteria in silages. However, thymol has been shown to inhibit the growth of $D$. hansenii (Curtis et al., 1996) and species of Pichia and Candida (Falcone et al., 2005). These yeasts have been identified as initiators of aerobic spoilage in silages (Pahlow et al., 2003). Similarly, limonene has been shown to be antifungal against species of Candida and Aspergillus flavus (Adegoke et al., 2000). In the current study, the blend of essential oils did not affect the numbers of yeasts and molds, enterobacteria, or lactic acid bacteria compared with untreated silage during the early stages of ensiling ( 3 and $8 \mathrm{~d}$, data not shown) and these findings were still found after $256 \mathrm{~d}$ of ensiling (Table 4). The exact reason for the lack of a measurable antifungal effect is unknown because the concentration of essential oils was within the range at which inhibition has been shown in pure culture, but this may have been due to inactivation of the essential oils in the complex environment of silage. When compared with untreated silage, the addition of the low and high doses of the essential oil mixture had no effect on DM recovery, fermentation end products, nutrient content, yeasts and molds, or aerobic stability. Addition of the buffered propionic acid additive moderately depressed the production of lactic and acetic acids when compared with untreated silage after $256 \mathrm{~d}$. As expected, concentrations of propionic acid were greatest for this treatment, which resulted in the smallest number of yeasts among treatments. However, because the depression in yeasts was relatively small, there was no effect of the additive on the aerobic stability of corn silage. Buffered propionic acid additives have decreased the number of yeasts and improved aerobic stability in past studies (Kung et al., 1998; Kung and Ranjit, 2001), and the reason for a lack of a response in the current study is unknown.

\section{Lactation Trial}

The average composition of the TMR fed to cows throughout the study is shown in Table 2. The diets were similar in nutrient composition. The distribution of feed particles suggested that the diets were marginal in effective fiber because the percentage of particles on the second screen was approximately $23 \%$, whereas recommendations suggest a 30 to $50 \%$ distribution on this screen (Heinrichs and Kononoff, 2002). 
Table 4. Dry matter recovery, silage $\mathrm{pH}$, chemical (DM basis) composition, microbial composition (wet basis), and aerobic stability of corn silages after $256 \mathrm{~d}$ of ensiling

\begin{tabular}{|c|c|c|c|c|c|}
\hline Treatment & Control $^{1}$ & $\mathrm{BEO},{ }^{2} 1 \times$ & $\mathrm{BEO},{ }^{3} 2 \times$ & $\begin{array}{c}\text { Buffered } \\
\text { propionic acid }\end{array}$ & SEM \\
\hline DM recovery, $\%$ & 89.9 & 86.4 & 88.6 & 88.1 & 1.1 \\
\hline $\mathrm{DM}, \%$ & $26.1^{\mathrm{b}}$ & $26.4^{\mathrm{b}}$ & $25.8^{\mathrm{b}}$ & $30.4^{\mathrm{a}}$ & 0.3 \\
\hline $\mathrm{pH}$ & $3.72^{\mathrm{a}}$ & $3.71^{\mathrm{a}}$ & $3.66^{\mathrm{ab}}$ & $3.64^{\mathrm{b}}$ & 0.02 \\
\hline Lactic acid, \% & $5.50^{\mathrm{a}}$ & $5.34^{\mathrm{a}}$ & $5.70^{\mathrm{a}}$ & $4.53^{\mathrm{b}}$ & 0.26 \\
\hline Acetic acid, \% & $2.20^{\mathrm{a}}$ & $1.98^{\mathrm{ab}}$ & $2.14^{\mathrm{a}}$ & $1.86^{\mathrm{b}}$ & 0.07 \\
\hline Propionic acid, $\%$ & $<0.01^{\mathrm{b}}$ & $<0.01^{\mathrm{b}}$ & $<0.01^{\mathrm{b}}$ & $0.53^{\mathrm{a}}$ & $<0.01$ \\
\hline Ammonia-N, \% & $0.229^{\mathrm{ab}}$ & $0.226^{\mathrm{ab}}$ & $0.248^{\mathrm{a}}$ & $0.201^{\mathrm{b}}$ & 0.015 \\
\hline Water soluble carbohydrates, $\%$ & $2.34^{\mathrm{b}}$ & $2.67^{\mathrm{b}}$ & $2.19^{\mathrm{b}}$ & $3.29^{\mathrm{a}}$ & 0.15 \\
\hline Yeasts, $\log _{10} \mathrm{cfu} / \mathrm{g}$ & $5.16^{\mathrm{a}}$ & $5.41^{\mathrm{a}}$ & $5.18^{\mathrm{a}}$ & $4.45^{\mathrm{b}}$ & 0.22 \\
\hline Molds, $\log _{10} \mathrm{cfu} / \mathrm{g}$ & 4.47 & 4.57 & 4.51 & 3.62 & 0.31 \\
\hline Aerobic stability, ${ }^{5} \mathrm{~h}$ & 47.5 & 45.3 & 49.5 & 59.5 & 4.2 \\
\hline
\end{tabular}

a,b Means within rows with unlike superscripts differ $(P<0.05)$.

${ }^{1}$ Untreated forage.

${ }^{2}$ Forage treated to achieve $40 \mathrm{mg}$ of a blend of essential oils (Crina, DSM Nutritional Products Ltd., Parsippany, $\mathrm{NJ})$ per kilogram of fresh forage.

${ }^{3}$ Forage treated to achieve $80 \mathrm{mg}$ of a blend of essential oils (Crina, DSM Nutritional Products Ltd.) per kilogram of fresh forage.

${ }^{4} \mathrm{~A}$ buffered propionic acid-based additive (Ultra Chem, Kemin Industries, West Des Moines, IA, added at $0.2 \%$ of fresh weight).

${ }^{5}$ The number of hours silage remained stable after exposure to air before a $2^{\circ} \mathrm{C}$ increase in temperature above ambient temperature.

Data from the lactation experiment are shown in Table 5. Dry matter intake was greater from cows fed essential oils $(28.3 \mathrm{~kg} / \mathrm{d})$ compared with cows fed the control diet $(26.4 \mathrm{~kg} / \mathrm{d})$. Similarly, DMI expressed as a percentage of BW was also greater for cows fed the essential oils. These findings are in contrast to a depression in DMI when cows were fed Crina, as reported by Tassoul and Shaver (2008), but cows were in a much earlier stage of lactation in their study. In our study, cows fed a TMR supplemented with essential oils tended $(P<0.16)$ to produce more milk $(41.7 \mathrm{~kg} / \mathrm{d})$ than cows fed the control diet $(39.8 \mathrm{~kg} / \mathrm{d})$. The percentage of fat in milk was numerically greater, although not statistically, in cows supplemented with essential oils. This finding led to an increase in milk fat production for cows fed the supplement (1.24 vs. $1.13 \mathrm{~kg} / \mathrm{d})$. Furthermore, $3.5 \%$ FCM was greater in cows fed essential oils (38.2 vs. $35.5 \mathrm{~kg} / \mathrm{d}$ ). Several studies have also evaluated the effectiveness of feeding the same blend of essential oils (Crina) as was used in the current study. Offer et al. (2005) fed cows 3 doses of Crina $(0.5,1.0$, and $2.0 \mathrm{~g} / \mathrm{d})$ and reported an increase of $1.2,1.6$, and $1.8 \mathrm{~kg}$ of $\mathrm{FCM} / \mathrm{d}$, respectively, for the 3 doses. In a field study, Varga et al. (2004) reported that feeding Crina improved FCM production by $1.6 \mathrm{~kg} / \mathrm{d}$. In studies by Benchaar et al. $(2006,2007)$, feeding the same product we used depressed FCM, but the number of cows per treatment was limited in those studies. Recently, Tassoul and Shaver (2008) reported that feeding Crina in early lactation did not affect milk production.

Overall, the milk fat content of the current study was low (approximately 2.9\%) and may have been a reflection of the low percentage of particles on the second

Table 5. Least squares means of performance data from lactating cows fed a TMR with or without a blend of essential oils

\begin{tabular}{lccc}
\hline Item & Control & BEO $^{1}$ & SEM \\
\hline DMI, kg/d & $26.4^{\mathrm{b}}$ & $28.3^{\mathrm{a}}$ & 0.5 \\
Milk & & & \\
Yield, kg/d & $39.8^{\mathrm{c}}$ & $41.7^{\mathrm{d}}$ & 0.9 \\
Fat, \% & 2.89 & 2.99 & 0.09 \\
Fat, kg/d & $1.13^{\mathrm{b}}$ & $1.24^{\mathrm{a}}$ & 0.03 \\
Protein, \% & 3.11 & 3.07 & 0.04 \\
Protein, kg/d & 1.23 & 1.27 & 0.02 \\
Urea N, mg/dL & 11.1 & 11.6 & 0.4 \\
Somatic cells/mL, $\times 1,000$ & 242 & 243 & 40 \\
$3.5 \%$ FCM, kg/d & $35.5^{\mathrm{a}}$ & $38.2^{\mathrm{b}}$ & 0.8 \\
DMI, \% of BW & $3.98^{\mathrm{b}}$ & $4.23^{\mathrm{a}}$ & 0.08 \\
Feed efficiency, DMI:FCM & 1.36 & 1.35 & 0.03 \\
BCS & 3.2 & 3.2 & 0.1 \\
Change in BCS ${ }^{2}$ & 0.07 & 0.16 & 0.06 \\
BW, kg & 662 & 671 & 8 \\
Change in BW, kg/d & 0.53 & 0.86 & 0.28 \\
\hline
\end{tabular}

${ }^{\mathrm{a}, \mathrm{b}}$ Means in rows with unlike superscripts differ $P<0.05$

${ }^{c, d}$ Means in rows with unlike superscripts differ $P<0.16$

${ }^{1}$ TMR supplemented with a blend of essential oils (Crina, DSM Nutritional Products Ltd., Parsippany, NJ) to supply $1.2 \mathrm{~g} /$ cow per

${ }^{2}$ Change over the 9 -wk treatment period. 
Table 6. Effects of a blend of essential oils (BEO) on ruminal fermentation after $12 \mathrm{~h}$ of incubation

\begin{tabular}{|c|c|c|c|c|c|c|}
\hline \multirow[b]{2}{*}{ Item } & \multirow[b]{2}{*}{ Control } & \multirow[b]{2}{*}{$\begin{array}{c}\mathrm{BEO},{ }^{1} \\
1 \times\end{array}$} & \multirow[b]{2}{*}{$\begin{array}{c}\mathrm{BEO},{ }^{2} \\
25 \times\end{array}$} & \multirow[b]{2}{*}{ SEM } & \multicolumn{2}{|c|}{ Contrast, $P$-value } \\
\hline & & & & & $\begin{array}{c}\text { Control vs. } \\
\text { BEO, } 1 \times \\
\text { and } \mathrm{BEO}, 25 \times\end{array}$ & $\begin{array}{c}\text { BEO, } 1 \times \\
\text { vs. BEO, } \\
25 \times\end{array}$ \\
\hline $\mathrm{pH}$ & 6.78 & 6.83 & 6.83 & 0.07 & $<0.25$ & $<0.87$ \\
\hline \multicolumn{7}{|l|}{ VFA, molar $\%$} \\
\hline Acetic acid & 67.33 & 64.55 & 66.41 & 1.23 & $<0.02$ & $<0.03$ \\
\hline Propionic acid & 22.97 & 27.08 & 24.07 & 1.75 & $<0.02$ & $<0.02$ \\
\hline Isobutyric acid & 1.52 & 1.33 & 1.61 & 0.20 & $<0.61$ & $<0.04$ \\
\hline Butyric acid & 5.52 & 4.95 & 5.29 & 0.22 & $<0.01$ & $<0.03$ \\
\hline Isovaleric acid & 1.39 & 0.99 & 1.39 & 0.24 & $<0.17$ & $<0.03$ \\
\hline Valeric acid & 1.27 & 1.10 & 1.23 & 0.07 & $<0.02$ & $<0.02$ \\
\hline Total VFA, mM & 76.45 & 72.17 & 75.74 & 5.12 & $<0.39$ & $<0.29$ \\
\hline
\end{tabular}

${ }^{1}$ A blend of essential oils (Crina, DSM Nutritional Products Ltd., Parsippany, NJ) at a physiological dose of $0.044 \mathrm{mg} / \mathrm{kg}$ of feed (DM basis).

${ }^{2} \mathrm{~A}$ blend of essential oils (Crina, DSM Nutritional Products Ltd.) at a dose of $1.111 \mathrm{mg} / \mathrm{kg}$ of feed (DM basis).

screen of the particle separator and the fat supplement, which contained tallow, poultry, and porcine fats. There were, however, no observed signs of laminitis during the study. Milk protein percentage, milk protein, MUN, and SCC were not affected by treatment. Feed efficiency was similar between treatments. Body score, change in body score, BW, and change in BW were also similar between treatments.

\section{In Vitro Fermentation}

After $12 \mathrm{~h}$, the addition of essential oils to in vitro ruminal fermentations had no effect on culture $\mathrm{pH}$ and total concentration of VFA (Table 6). Addition of essential oils decreased the molar proportion of acetic, butyric, and valeric acids, but increased the molar proportion of propionic acid. When compared with the moderate dose of essential oils, the larger dose increased the molar proportions of acetic, isobutyric, butyric, isovaleric, and valeric acids but decreased the molar proportion of propionic acid. Effects of essential oils on ruminal fermentation have been extremely variable (Calsamiglia et al., 2006) and may be affected by diet and rumen $\mathrm{pH}$ (Castillejos et al., 2005), the system in which they are evaluated (in vivo, batch in vitro, or continuous culture; Benchaar et al., 2006), and the length of the fermentation process (Cardozo et al., 2004).

\section{CONCLUSIONS}

A blend of essential oils added to corn forage at ensiling did not affect the microorganisms, the fermentation process, or the aerobic stability of corn silage.
When added as a physiological dose to in vitro ruminal fermentations, the blend of essential oils reduced the molar proportion of acetate but increased the molar proportion of propionate, which may partially explain why, when fed to lactating dairy cows, the blend of essential oils increased DMI and 3.5\% FCM production.

\section{ACKNOWLEDGMENTS}

The authors thank the farm staff of the University of Delaware Dairy for harvesting the crops and Richard Morris, dairy herdsman, for care of the animals.

\section{REFERENCES}

Adegoke, G. O., H. Iwahashi, Y. Komatsu, K. Obuchi, and Y. Iwahashi. 2000. Inhibition of food spoilage yeasts and aflatoxigenic moulds by monoterpenes of the spice Aframomum danielli. Flavour Fragrance J. 15:147-150.

Agricultural Animal Care and Use Committee. 1989. Handbook for Agricultural Animal Care and Use in Research and Teaching. Agric. Anim. Care and Use Committee, Univ. Delaware, Coll. Agric. Natural Res., Newark.

Benchaar, C., H. V. Petit, R. Berthiaume, D. R. Ouellet, J. Chiquette, and P. Y. Chouinard. 2006. Effects of addition of essential oils and monensin premix on digestion, ruminal fermentation, milk production, and milk composition in dairy cows. J. Dairy Sci. 89:4352-4364.

Benchaar, C., H. V. Petit, R. Berthiaume, D. R. Ouellet, J. Chiquette, and P. Y. Chouinard. 2007. Effects of essential oils on digestion, ruminal fermentation, rumen microbial populations, milk production, and milk composition in dairy cows fed alfalfa silage or corn silage. J. Dairy Sci. 90:886-897.

Broudiscou, L. P., and B. Lassalas. 2000. Effects of Lavandula officinalis and Equisetum arvense dry extracts and isoquercitrin on the fermentation of diets varying in forage contents by rumen microorganisms in batch culture. Reprod. Nutr. Dev. 40:431440.

Burt, S. 2004. Essential oils: Their antibacterial properties and potential applications on foods - A review. Int. J. Food Microbiol. 94:223-253. 
Calsamiglia, S., M. Busquet, P. W. Cardozo, L. Castillejos, and A. Ferret. 2006. Essential oils as modifiers of rumen microbial fermentation. J. Dairy Sci. 90:2580-2595.

Cardozo, P. W., S. Calsamiglia, A. Ferret, and C. Kamel. 2004 Screening for the effects of a natural plant extracts at different $\mathrm{pH}$ on in vitro rumen microbial fermentation of a high-concentrate diet for beef cattle. J. Anim. Sci. 83:2572-2579.

Castillejos, L., S. Calsamiglia, A. Ferret, and R. Losa. 2005. Effects of a specific blend of essential oil compounds and the type of diet on rumen microbial fermentation and nutrient flow from a continuous culture system. Anim. Feed Sci. Technol. 119:29-41.

Chao, S. C., D. G. Young, and C. J. Oberg. 2000. Screening for inhibitory activity of essential oils on selected bacteria, fungi and viruses. J. Essential Oil Res. 12:639-649.

Cichewicz, R. H., and P. A. Thorpe. 1996. The antimicrobial properties of chile peppers (Capsicum species) and their uses in Mayan medicine. J. Ethnopharmacol. 52:61-70.

Curtis, O. F., K. S. Hetty, G. Cassagnol, and M. Peleg. 1996 Comparison of the inhibitory and lethal effects of synthetic versions of plant metabolites (anethole, carvacrol, eugenol, and thymol) on food spoilage yeast (Debaromyces hansenii). Food Biotechnol. 10:55-73.

Falcone, P., B. Speranza, M. A. Nobile, M. R. Corbo, and M. Sinigaglia. 2005. A study on the antimicrobial activity of thymol intended as a natural preservative. J. Food Prot. 68:1664-1670.

Ferme, D., M. Banjac, S. Calsamiglia, M. Busquet, C. Kamel, and G. Avguštin. 2004. The effect of plant extracts on microbial community structure in a rumen-simulating continuous-culture system as revealed by molecular profiling. Folia Microbiol. (Praha) 49:151-155.

Figueiredo, A. R., F. Campos, V. de Freitas, T. Hogg, and J. A. Couto 2008. Effect of phenolic aldehydes and flavonoids on growth and inactivation of Oenococcus oeni and Lactobacillus hilgardii. Food Microbiol. 25:105-112.

Goering, H. K., and P. J. Van Soest. 1970. Forage Fiber Analysis (Apparatus, Reagents, Procedures, and Some Applications). Agric. Handbk. No. 3790. ARS-USDA, Washington, DC.

Heinrichs, J. A., and P. Kononoff. 2002. Evaluating particle size of forages and TMR using the new Penn State forage separator. DAS020-42. Coll. Agric. Sci., Pennsylvania State Univ., State College.

Ismaiel, A., and M. D. Pierson. 1990. Inhibition of growth and germination of $C$. botulinum 33A, 40B, and 1623E by essential oil of species. J. Food Sci. 55:1676-1678.

Juglal, S., R. Govinden, and B. Odhav. 2002. Spice oils for the control of co-occurring mycotoxin-producing fungi. J. Food Prot. 65:683687

Kamel, C. 2001. Tracing modes of action and the roles of plant extracts in nonruminants. Pages 135-150 in Recent Advances in Animal Nutrition. P. C. Barnsworthy and J. Wiseman, ed. Nottingham University Press, Nottingham, UK.

Kim, H. G., J. H. Cho, E. Y. Jeong, J. H. Lim, S. H. Lee, and H. S. Lee. 2006. Growth-inhibiting activity of active component isolated from Terminalia chebula fruits against intestinal bacteria. J. Food Prot. 69:2205-2209.

Kivanc, M., A. Akgulm, and A. Dogan. 1991. Inhibitory and stimulatory effects of cumin, oregano and their essential oils on growth and acid production of Lactobacillus plantarum and Leuconostoc mesenteroides. Int. J. Food Microbiol. 13:81-86.

Knowles, J., and S. Roller. 2001. Efficacy of chitosan, carvacrol, and a hydrogen peroxide-based biocide against foodborne microorganisms in suspension and adhered to stainless steel. J. Food Prot. 64:1542-1548.

Kung, L. Jr, and N. K. Ranjit. 2001. The effect of Lactobacillus buchneri and other additives on the fermentation and aerobic stability of barley silage. J. Dairy Sci. 84:1149-1155.
Kung, L. Jr, A. C. Sheperd, A. M. Smagala, K. M. Endres, C. A Bessett, N. K. Ranjit, and J. L. Glancey. 1998. The effect of propionic acid-based preservatives on the fermentation and aerobic stability of corn silage and a total mixed ration. J. Dairy Sci. $81: 1322-1330$.

Kung, L., Jr., M. A. Stokes, and C. J. Lin. 2003. Silage additives. Pages 305-360 in Silage Science and Technology. D. R. Buxton, R. E. Muck, and J. H. Harrison, ed. Am. Soc. Agron., Madison, WI.

McIntosh, F. M., P. Williams, R. Losa, R. J. Wallace, D. A. Beever and C. J. Newbold. 2003. Effects of essential oils on ruminal microorganisms and their protein metabolism. Appl. Environ. Microbiol. 69:5011-5014.

NRC. 2001. Nutrient Requirements of Dairy Cattle. 7th rev. ed. Natl. Acad. Sci., Washington, DC.

Nelson, N. 1944. A photometric adaptation of the Somogyi method for the determination of glucose. J. Biol. Chem. 153:375-380.

Newbold, C. J., F. M. McIntosh, P. Williams, R. Losa, and R. J Wallace. 2004. Effects of a specific blend of essential oil compounds on rumen fermentation. Anim. Feed Sci. Technol. 114:105-112.

Offer, N. W.. J. F. Bell, and D. J. Roberts. 2005. The effect of feeding an essential oil feed additive on dairy cattle performance. Page 188, Abstr. 188. Proc. Br. Soc. Anim. Sci. Br. Soc. Anim. Sci., Midlothian, UK.

Okuda, H., S. Fuji, and Y. Kawashima. 1965. A direct colorimetric method for blood ammonia. Tokushima J. Exp. Med. 12:11-13.

Pahlow, G., R. E. Muck, F. Driehuis, S. J. W. H. Oude Elferink, and S. F. Spoelstra. 2003. Microbiology of ensiling. Pages 31-94 in Silage Science and Technology. D. R. Buxton, R. E. Muck, and J. H. Harrison, ed. Am. Soc. Agron., Madison, WI.

Robertson, J. B., and P. J. Van Soest. 1981. The detergent system of analysis and it application to human foods. Pages 123-158 in The Analysis of Dietary Fiber in Food. W. P. T. James and O. Theander, ed. Marcel Dekker Inc., New York, NY

Russell, J. B., R. Onodera, and T. Hino. 1991. Ruminal protein fermentation: New perspectives on previous contradictions. Pages 681-697 in Physiological Aspects of Digestion and Metabolism in Ruminants. T. Tsuda, Y. Sasaki, and R. Kawashima, eds. Academic Press, San Diego, CA.

Smid, E. J., and L. G. M. Gorris. 1999. Natural antimicrobials for food preservation. Pages 285-308 in Handbook of Food Preservation. M. S. Rahman, ed. Marcel Dekker, New York, NY.

Snedecor, G. W., and W. G. Cochran. 1980. Statistical Methods. 6th ed. Iowa State Univ. Press, Ames.

Tassoul, M. D., and R. D. Shaver. 2008. Efficacy of essential oils as dietary supplements for dairy cows. Page $24-32$ in Proc. 6th MidAtlantic Nutrition Conf. Timonium, MD. N. G. Zimmermann, ed., Univ. Maryland, College Park.

Van Soest, P. J., J. B. Robertson, and B. A. Lewis. 1991. Methods for dietary fiber, neutral detergent fiber, and nonstarch polysaccharides in relation to animal nutrition. J. Dairy Sci. 74:3583-3597.

Varga, G., E. Block, P. Williams, T. W. Cassidy, and R. Losa. 2004. Effect of Crina Ruminants, a mixture of essential oil components, on continuous culture fermentation and milk production of lactating cows. J. Dairy Sci. 87(Suppl. 1):334 (Abstr.)

Wallace, R. J. 2004. Antimicrobial properties of plant secondary metabolites. Symposium: Plants as animal foods: A case of catch 22. Proc. Nutr. Soc. 63:621-629.

Wildman, E. E., G. M. Jones, P. E. Wagner, R. L. Boman, H. F. Troutt Jr, and T. N. Lesch. 1982. A dairy cow body condition scoring system and its relationship to selected production characteristics. J. Dairy Sci. 65:495-501. 